\title{
PENGARUH BERBAGAI RASIO ENERGI PROTEIN PADA PAKAN ISO PROTEIN 30\% TERHADAP KINERJA PERTUMBUHAN BENIH IKAN PATIN (Pangasius hypophthalmus)
}

\author{
Mas Bayu Syamsunarno, Ing Mokoginta, dan Dedi Jusadi \\ Departemen Budidaya Perairan-FPIK, Institut Pertanian Bogor \\ Jl. Lingkar Akademik, Kampus IPB Darmaga, Bogor 16680 \\ E-mail: mastrimm@yahoo.co.id
}

(Naskah diterima: 26 Januari 2010; Disetujui publikasi: 25 Maret 2011)

\begin{abstract}
ABSTRAK
Tujuan percobaan ini adalah untuk menentukan rasio energi protein optimum yang menghasilkan pertumbuhan maksimum benih ikan patin (Pangasius hypophthalmus). Percobaan menggunakan 5 (lima) pakan iso protein dengan rasio energi protein berbeda, yaitu: 8,$5 ; 9,0 ; 9,5 ; 10,0$; dan 10,5 kkal DE/g protein. Benih patin berukuran $1,84 \pm 0,02 \mathrm{~g}$ ditebar secara acak ke dalam 15 akuarium $(50 \mathrm{~cm} \times 40 \mathrm{~cm} \times 35 \mathrm{~cm})$ dengan kepadatan 20 ekor per akuarium. Benih ikan patin tersebut diberi pakan uji dua kali sehari sekenyangnya (satiation) selama 40 hari. Hasil percobaan menunjukkan bahwa kandungan protein tubuh tertinggi dihasilkan oleh pakan dengan rasio energi protein $9,0 \mathrm{kkal} D E / g$ protein, sedangkan lemak tubuh terendah dicapai oleh perlakuan $8,5 \mathrm{kkal} \mathrm{DE} / \mathrm{g}$ protein. Namun, protein karkas adalah sama untuk perlakuan $8,5-9,5$ $\mathrm{kkal} \mathrm{DE} / \mathrm{g}$ protein dan kandungan lemak karkas terendah dicapai oleh 8,5 kkal DE/g protein. Konsumsi pakan, retensi protein, dan pertumbuhan tertinggi dihasilkan oleh pakan dengan rasio energi protein $9,0 \mathrm{kkal} D E / g$ protein $(\mathrm{P}<0,05)$ dan konversi pakan tidak berbeda nyata antar perlakuan $(P>0,05)$. Oleh karena itu, kandungan optimum rasio energi protein $9,0 \mathrm{kkal} \mathrm{DE} / \mathrm{g}$ protein memberikan pertumbuhan tertinggi pada benih ikan patin.
\end{abstract}

KATA KUNCl: benih patin, Pangasius hypophthalmus, rasio energi protein

ABSTRACT: The effect of different energy-protein ratios in iso protein diet (30\%) on the growth performance of Pangasius hypophthalmus fry. By: Mas Bayu Syamsunarno, Ing Mokoginta, and Dedi Jusadi

The aim of this experiment was to determine the optimum dietary energy to protein ratio at protein level of $30 \%$ that could produce maximum growth rate of catfish fry (Pangasius hypophthalmus). This experiment used five iso-protein diets with difference in energy protein ratio: 8.5, 9.0, 9.5, 10.0 and $10.5 \mathrm{kcal} D E / g$ protein. Catfish fry with individual body weight of $1.84 \pm 0.02 \mathrm{~g}$ was randomly stocked in 15 aquariua $(50 \times 40 \times 35 \mathrm{~cm})$ at the density of 20 each. The fries were fed on the experimental diets two times daily at satiation for 40 days. Results of this experiment showed that the highest body protein level was produced by the diet with energy to protein ratio of $9.0 \mathrm{kcal} \mathrm{DE} / \mathrm{g}$ protein, while the lowest body fat level was produced by $8.5 \mathrm{kcal} \mathrm{DE} / \mathrm{g}$ protein. However, the protein level of carcass was comparable at 8.5$9.0 \mathrm{kcal} \mathrm{DE} / \mathrm{g}$ protein and the lowest fat level of the carcass was at the treatment of $8.59 .0 \mathrm{kcal} D E / g$ protein. The highest feed consumption, protein retention and growth rate was performed by dietary energy to protein ratio of $9.0 \mathrm{kcal} D E / g$ protein $(P<0.05)$ and the feed conversion ratio was not significantly different among treatments 
$(P>0.05)$. It was concluded that the optimum dietary energy to protein ratio for catfish fry was $9.0 \mathrm{kcal} \mathrm{DE} / \mathrm{g}$ protein.

\section{KEYWORDS: catfish fry, Pangasius hypophthalmus, energy-protein ratio}

\section{PENDAHULUAN}

Intensivikasi usaha budidaya patin membutuhkan jaminan kesinambungan benih sesuai dengan permintaan. Salah satu faktor yang mempengaruhi produksi benih ikan adalah ketersediaan pakan bermutu tinggi untuk jenis komoditas yang dibudidayakan tersebut. Salah satu aspek penilaian terhadap mutu pakan yang terpenting adalah rasio energi protein pakan. Penentuan rasio energi dan protein pakan optimum dibutuhkan untuk mendapatkan pertumbuhan ikan maksimum. Hal ini disebabkan pertumbuhan hanya dapat terjadi jika kebutuhan energi untuk pemeliharaan proses-proses hidup dan fungsifungsi lainnya telah terpenuhi (Brett \& Grovers, 1979). Jika kandungan energi pakan rendah, maka protein pakan akan digunakan sebagai sumber energi. Sebaliknya, kelebihan energi akan menyebabkan nafsu makan ikan akan berkurang sehingga pertumbuhan ikan akan menurun. Jadi pakan harus mempunyai rasio energi protein tertentu yang dapat menyediakan energi non protein dalam jumlah yang cukup agar protein pakan sebagian besar digunakan untuk pertumbuhan.

Informasi mengenai rasio energi protein pakan untuk jenis ikan patin (Pangasius sp.) dan kelompok catfish lainnya telah tersedia. Benih ikan patin jambal (Pangasius djambal) ukuran $7,6 \mathrm{~g}$ yang diberi pakan dengan kadar protein $35 \%$, lemak $6,25 \%$ dan karbohidrat $36,14 \%$ serta rasio energi protein $7,5 \mathrm{kkal} / \mathrm{g}$ protein dapat tumbuh secara maksimum (Suhenda et al., 2003). Benih ikan baung (Mystus nemurus) ukuran 0,28 g membutuhkan pakan yang mengandung protein $35 \%$, lemak $12,91 \%$, dan karbohidrat $32,99 \%$ dengan rasio energi protein $8,11 \mathrm{kkal} / \mathrm{g}$ protein untuk mencapai pertumbuhan maksimumnya (Suryanti et al., 2003). Kurnia (2002) menyatakan bahwa benih ikan baung ( $M$. nemurus) ukuran 5,3 g mengalami pertumbuhan terbaik pada tingkat protein pakan 29\% (lemak 6,3\% dan karbohidrat 49,79\%) dengan rasio energi protein 11,47 kkal/g protein. Menurut Rebegnatar \& Hidayat (1992), benih ikan lele dengan bobot rata-rata 1,22$1,56 \mathrm{~g}$ membutuhkan rasio energi protein di bawah 9,23-9,83 $\mathrm{kkal} / \mathrm{mg}$ protein dengan kadar protein 30,99\%. NRC (1982) berpendapat bahwa rasio energi protein $8-9 \mathrm{kkal} / \mathrm{g}$ protein memberikan pertumbuhan maksimum pada benih channel catfish ukuran sejari. Lovell (1989) menambahkan bahwa rasio optimum digestible energy (DE)-protein untuk tingkat pertumbuhan maksimum channel catfish berukuran 3-250 g adalah 10-11 kkal/g protein. Subamia et al. (2003) menyatakan bahwa pakan yang mengandung protein $35,4 \%$; lemak $4 \%$; dan karbohidrat $43,86 \%$ dengan rasio energi protein pakan $8,43 \mathrm{kkal} / \mathrm{g}$ protein menghasilkan pertumbuhan optimum benih jambal siam ( $P$. hypophthalmus) ukuran $1,52 \mathrm{~g}$.

Mengingat protein pakan mempunyai harga yang lebih mahal, perlu kiranya menurunkan kadar protein di bawah 35\% yang mampu menghasilkan pertumbuhan relatif sama. Oleh karena itu, suatu penelitian perlu dirancang untuk benih ikan patin $(P$. hypophthalmus) dengan menggunakan kadar protein $30 \%$ dengan rasio energi protein berbeda. Tujuan dari penelitian ini adalah untuk mendapatkan rasio energi protein pakan pada kadar protein pakan $30 \%$ yang terbaik untuk benih ikan patin.

\section{BAHAN DAN METODE}

\section{Pakan Uji}

Pakan uji yang digunakan dalam penelitian ini adalah pakan buatan yang mengandung protein $30 \%$. Pakan tersebut mempunyai rasio energi (digestible energy,DE)-protein berbeda, yaitu 8,$5 ; 9,0 ; 9,5 ; 10,0 ;$ dan $10,5 \mathrm{kkal} / \mathrm{g}$ protein. Pakan uji tersusun atas tepung ikan dan tepung kedelai sebagai sumber protein utama. Minyak jagung dan minyak ikan digunakan sebagai sumber energi dengan rasio $2: 1$. Pengaturan rasio energi protein pakan sesuai dengan rancangan penelitian adalah dengan menambahkan minyak. Bahan pakan lain yang digunakan dalam penelitian adalah tepung pollar, tepung terigu, vitamin mix komersial, mineral mix komersial, vitamin $\mathrm{C}, \mathrm{Ca}\left(\mathrm{PO}_{4}\right)_{2}$, choline chloride, metionin, dan lisin. Rasio protein hewani dan nabati pakan 
mendekati $1: 1$. Bahan pakan uji yang telah ditetapkan diproses menjadi pakan berbentuk pelet berdiameter $2 \mathrm{~mm}$. Komposisi pakan dan hasil analisis proksimat pakan uji yang digunakan masing-masing tercantum pada Tabel 1 dan 2.

\section{Pemeliharaan Ikan dan Pengumpulan Data}

Ikan uji yang digunakan adalah ikan patin yang mempunyai bobot awal rata-rata $1,84 \pm 0,02 \mathrm{~g}$. Ikan uji tersebut ditebar secara acak ke dalam 15 buah akuarium masing-masing berukuran $50 \mathrm{~cm} \times 40 \mathrm{~cm} \times 35 \mathrm{~cm}$ yang diisi air sampai ketinggian $30 \mathrm{~cm}$ dengan kepadatan 20 ekor/akuarium. Akuarium dilengkapi dengan sistem resirkulasi dan diberikan penutup plastik agar ikan tidak keluar dari wadah pemeliharaan. Penyiponan dilakukan setiap dua hari sekali pada tiap akuarium, yaitu pada pagi sebelum dilakukan pemberian pakan. Air yang terbuang sebanyak $25 \%-50 \%$ dari total volume akuarium diganti dengan air yang baru. Ikan uji tersebut kemudian diadaptasikan terhadap pakan uji, media hidup dan wadah pemeliharaan selama 2 (dua) hari. Setelah dilakukan aklimatisasi, ikan uji dipuasakan selama 24 jam untuk menghilangkan sisa pakan dalam saluran pencernaan ikan. Air yang digunakan untuk pemeliharaan terlebih dahulu diendapkan dan diaerasi minimal selama 24 jam dalam bak penampungan. Data kualitas air yang diperoleh selama penelitian adalah suhu air berkisar antara $29-31^{\circ} \mathrm{C}, \mathrm{pH}$ 6-7, oksigen terlarut 6,25-6,47 mg/L, alkalinitas $2,33 \mathrm{mg} / \mathrm{L}$ dan amonia- $\mathrm{N}\left(\mathrm{NH}_{3}-\mathrm{N}\right) 0,001 \mathrm{mg} / \mathrm{L}$. Nilai parameter kualitas tersebut dapat menunjang pertumbuhan ikan dengan baik.

Pemeliharaan ikan uji dilakukan selama 40 hari. Ikan tersebut diberi pakan sampai sekenyangnya (satiation) dengan frekuensi pemberian pakan sebanyak 2 kali yakni pukul

Tabel 1. Komposisi bahan pakan yang digunakan dalam percobaan ( $\mathrm{g} / 100 \mathrm{~g}$ pakan)

Table 1. Composition of feed ingredients used in the experiment $(\mathrm{g} / 100 \mathrm{~g}$ feed)

\begin{tabular}{|c|c|c|c|c|c|}
\hline \multirow{2}{*}{$\begin{array}{l}\text { Bahan baku } \\
\text { Feed ingredients }\end{array}$} & \multicolumn{5}{|c|}{$\begin{array}{l}\text { Rasio energi-protein ( } \mathrm{kkal} / \mathrm{g} \text { protein) } \\
\text { Energy to protein ratio (kcal/g protein) }\end{array}$} \\
\hline & 8.5 & 9.0 & 9.5 & 10.0 & 10.5 \\
\hline Tepung ikan (Fish meal) & 22.00 & 19.69 & 19.69 & 19.69 & 19.75 \\
\hline Tepung kacang kedelai (Soybean meal) & 27.50 & 32.00 & 32.50 & 33.00 & 33.50 \\
\hline Tepung terigu (Wheat meal) & 15.00 & 15.00 & 15.00 & 15.00 & 15.00 \\
\hline Tepung pollar (Pollar meal) & 33.82 & 28.83 & 25.73 & 22.83 & 19.57 \\
\hline Vitamin mix & 0.13 & 0.13 & 0.13 & 0.13 & 0.13 \\
\hline Mineral mix & 0.30 & 0.30 & 0.30 & 0.30 & 0.30 \\
\hline Vitamin C & 0.05 & 0.05 & 0.05 & 0.05 & 0.05 \\
\hline $\mathrm{Ca}\left(\mathrm{PO}_{4}\right)_{2}$ & 0.30 & 0.30 & 0.30 & 0.30 & 0.30 \\
\hline Minyak ikan (Fish oil) & 0.00 & 1.00 & 1.80 & 2.60 & 3.40 \\
\hline Minyak jagung (Corn meal) & 0.20 & 2.00 & 3.80 & 5.40 & 7.30 \\
\hline Metionin (Methionine) & 0.10 & 0.10 & 0.10 & 0.10 & 0.10 \\
\hline Lysin (Lysine) & 0.10 & 0.10 & 0.10 & 0.10 & 0.10 \\
\hline Choline Chloride & 0.50 & 0.50 & 0.50 & 0.50 & 0.50 \\
\hline Total & 100.00 & 100.00 & 100.00 & 100.00 & 100.00 \\
\hline
\end{tabular}

Keterangan (Note):

Kandungan protein (\% bobot kering) tepung ikan 67,04\%, tepung bungkil kedelai 40,45\%, tepung terigu $11,58 \%$, dan tepung pollar 6,71\%, "Vitamin mix dan mineral mix komersial untuk ikan

Protein content (\% dried weight) of fish meal (67.04\%), soybean meal (40.45\%), wheat meal (1 1.58\%), and pollard meal (6.71\%), *Commercial premix vitamin and mineral for fish 
Tabel 2. Komposisi proksimat, kandungan energi, dan rasio energi protein pakan uji untuk ikan patin (\% bobot kering)

Table 2. Proximate composition, energy content, and energy to protein ratio of dietary test for catfish (\% dried weight)

\begin{tabular}{|c|c|c|c|c|c|}
\hline \multirow{2}{*}{$\begin{array}{l}\text { Komposisi proksimat (\%) } \\
\text { Proximate composition }\end{array}$} & \multicolumn{5}{|c|}{$\begin{array}{l}\text { Rasio energi-protein (kkal/g protein) } \\
\text { Energy to protein ratio (kcal/g protein) }\end{array}$} \\
\hline & 8.5 & 9.0 & 9.5 & 10.0 & 10.5 \\
\hline Protein kasar (Crude protein) & 29.9 & 29.6 & 29.7 & 29.8 & 29.8 \\
\hline Lemak kasar (Crude fat) & 4.8 & 7.7 & 9.3 & 11.3 & 15.5 \\
\hline Abu kasar (Crude ash) & 7.5 & 8.2 & 7.1 & 5.6 & 8.8 \\
\hline Serat kasar (Crude fiber) & 6.7 & 7.2 & 5.7 & 5.5 & 6.3 \\
\hline BETN $^{*}$ & 51.1 & 47.3 & 48.2 & 47.8 & 39.6 \\
\hline $\begin{array}{l}\text { Total energi (kkal/100 g prote in) } \\
\text { Total energy (Kcal/100 g protein) }\end{array}$ & 256.1 & 269.1 & 285.1 & 300.3 & 314.4 \\
\hline $\begin{array}{l}\text { Rasio DE-P (kkal/g prote in })^{*-*} \\
\text { Ratio DE-P (kcal/g protein })\end{array}$ & 8.6 & 9.1 & 9.6 & 10.1 & 10.6 \\
\hline
\end{tabular}

Keterangan (Remarks):

BETN : Bahan Ekstrak Tanpa Nitrogen (Nitrogen Free Extraxt Material)

DE-P : Digestable Energy-Protein

** DE Protein $=3,0 \mathrm{kkal} / \mathrm{g}$ protein, DE Lemak $(f a t)=8,1 \mathrm{kkal} / \mathrm{g}$ protein

DE karbohidrat (carbohydrate) $=2,5 \mathrm{Kkal} / \mathrm{g}$ protein (Furuichi, 1988)

08.00-09.00 dan 17.00-18.00 WIB. Jumlah pakan harian tersebut dicatat dan pada akhir penelitian digunakan untuk mengukur konsumsi pakan. Penimbangan bobot dilakukan pada awal dan akhir penelitian. Bobot yang diukur adalah biomassa ikan. Sebelum dilakukan penimbangan, ikan terlebih dahulu dipuasakan selama 24 jam. Pengukuran bobot bertujuan untuk mengetahui tingkat pertumbuhan. Sedangkan ikan yang mati selama periode pengamatan dihitung dan ditimbang, selanjutnya digunakan dalam penghitungan efisiensi pakan. Sampel tubuh ikan pada awal dan akhir percobaan dari setiap wadah diambil masing-masing sebanyak 10 dan 8 ekor untuk dianalisis kandungan protein dan lemaknya.

\section{Analisis Kimia}

Analisis proksimat terdiri atas protein, lemak, serat kasar, abu, dan kadar air dari masing-masing bahan antara lain: bahan pakan uji, pakan uji, tubuh ikan serta daging. Metode analisis proksimat mengikuti prosedur sesuai dengan Takeuchi (1988). Kandungan kadar protein ditentukan dengan metode Kjedahl, lemak dengan metode ekstraksi dengan alat Sokhlet dan Folch, kadar abu melalui pemanasan sampel dalam tanur pada suhu $400-600^{\circ} \mathrm{C}$, kadar serat kasar dengan metode pelarutan sampel dalam asam dan basa kuat serta pemanasan dan kadar air dengan metode pemanasan dalam oven pada suhu 105-1 10 ${ }^{\circ} \mathrm{C}$. Analisis proksimat bahan penyusun pakan dan pakan uji dilakukan pada awal penelitian. Analisis proksimat tubuh ikan dilakukan pada awal dan akhir percobaan.

\section{Analisis Statistik}

Rancangan percobaan yang digunakan adalah Rancangan Acak Lengkap (RAL) dengan lima perlakuan dan tiga ulangan. Untuk mengetahui pengaruh perlakuan terhadap tingkat sintasan, konsumsi pakan, pertumbuhan relatif, retensi protein, retensi lemak dan efisiensi pakan digunakan sidik ragam (uji F) pada tingkat kepercayaan 95\% dan dilanjutkan dengan uji lanjut uji Duncan. Paramater yang dievaluasi adalah tingkat sintasan, konsumsi pakan, pertumbuhan relatif, retensi protein, retensi lemak, dan efisiensi pakan. 


\section{HASIL DAN BAHASAN}

\section{Hasil}

Hasil pemberian pakan dengan rasio energi protein pakan yang berbeda pada ikan patin yang dipelihara selama 40 hari menunjukkan bahwa bobot rata-rata ikan meningkat dari awal hingga akhir pemeliharaan (Gambar 1). Berdasarkan gambar tersebut dapat dilihat bahwa bobot rata-rata ikan tertinggi terjadi pada rasio $9,0 \mathrm{kkal} / \mathrm{g}$ protein yakni sebesar $16,6 \mathrm{~g}$ dan diikuti pada rasio $8,5 \mathrm{kkal} / \mathrm{g}$ protein sebesar $15,2 \mathrm{~g}$; rasio $9,5 \mathrm{kkal} / \mathrm{g}$ protein sebesar $14,5 \mathrm{~g}$; rasio $10,0 \mathrm{kkal} / \mathrm{g}$ protein sebesar $14,0 \mathrm{~g}$; dan terendah pada rasio 10,5 $\mathrm{kkal} / \mathrm{g}$ protein sebesar 13,2 g.

Pemberian pakan dengan rasio energi protein yang berbeda dalam pakan dapat mempengaruhi tingkat konsumsi pakan, pertumbuhan relatif, retensi protein, retensi lemak, dan efisiensi pakan, sedangkan tingkat sintasan adalah sama antar perlakuan (Tabel 3). Konsumsi pakan pada ikan patin tertinggi dicapai pada pakan $9,0 \mathrm{kkal} / \mathrm{g}$ protein, kemudian diikuti oleh $8,5 \mathrm{kkal} / \mathrm{g}$ protein. Namun konsumsi pakan pada $8,5 \mathrm{kkal} / \mathrm{g}$ protein lebih tinggi dari perlakuan 9,5-10,5 $\mathrm{kkal} / \mathrm{g}$ protein. Adanya perbedaan jumlah pakan yang dikonsumsi sebagai akibat perbedaan rasio energi protein pakan memberi pola kepada penyimpanan nutrien dalam tubuh ikan patin. Hasil penelitian menunjukkan bahwa terlihat perbedaan nilai retensi protein pada ikan patin yang diberi pakan dengan rasio energi protein yang berbeda. Retensi protein tertinggi diamati pada pakan $9,0 \mathrm{kkal} / \mathrm{g}$ protein $(65,5 \%)$, sedangkan nilai retensi protein perlakuan lainnya tidak berbeda yakni berkisar 50,0\%-60,3\%.

Untuk retensi lemak, terjadi penurunan nilainya seiring dengan meningkatnya rasio energi protein pakan. Retensi lemak tertinggi pada rasio energi protein $8,5 \mathrm{kkal} / \mathrm{g}$ protein yaitu sebesar $124,1 \%$. Pemberian pakan dengan rasio energi protein $9,0 \mathrm{kkal} / \mathrm{g}$ protein menghasilkan retensi lemak lebih tinggi daripada 9,5-10,5 kkal/g protein. Perbedaan rasio energi protein dalam pakan memberikan pertumbuhan relatif yang berbeda pada ikan patin. Data menunjukkan bahwa pertumbuhan relatif tertinggi terjadi pada pakan yang mengandung $9,0 \mathrm{kkal} / \mathrm{g}$ protein, kemudian diikuti oleh $8,5 \mathrm{kkal} / \mathrm{g}$ protein. Pertumbuhan relatif pada 9,5-10,5 kkal/g protein relatif sama dan lebih rendah dari perlakuan lainnya.

Komposisi proksimat tubuh ikan pada Tabel 4 menunjukkan bahwa pemberian pakan dengan rasio energi protein yang berbeda memberikan kecenderungan penurunan kandungan air tubuh dengan naiknya rasio energi protein pakan. Protein tubuh meningkat

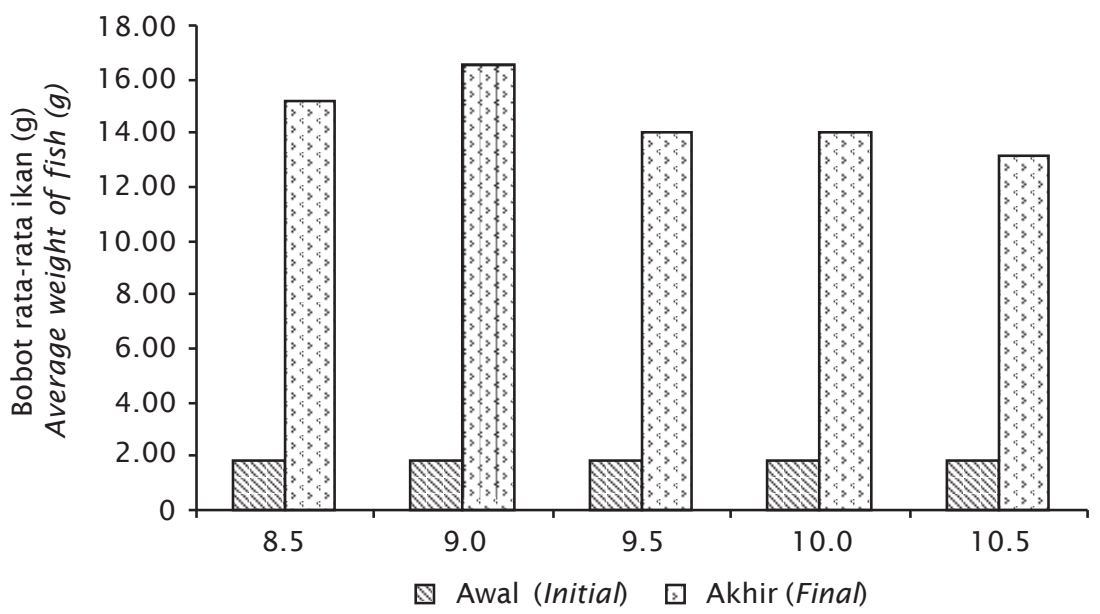

Rasio energi-protein (kkl/g protein) Energy to protein ratio ( $\mathrm{kcal} / \mathrm{g}$ protein)

Gambar 1. Bobot rata-rata ikan patin pada awal dan akhir penelitian

Figure 1. Average weight of catfish fry at the initial and the end of the study 
Tabel 3. Kinerja pertumbuhan benih ikan patin yang diberi pakan uji selama 40 hari masa pemeliharaan

Table 3. Growth performance of catfish fry fed on dietary test for 40 days of culture period

\begin{tabular}{lccccc}
\hline \multirow{2}{*}{$\begin{array}{c}\text { Parameter } \\
\text { Paramet er }\end{array}$} & \multicolumn{5}{c}{$\begin{array}{c}\text { Rasio Energi-protein (kkal/g protein) } \\
\text { Energyto protein ratio (kcal/g protein) }\end{array}$} \\
\cline { 2 - 6 } & $\mathbf{8 . 5}$ & $\mathbf{9}$ & $\mathbf{9 . 5}$ & 10 & 10.5 \\
\hline 1. SR (\%) & $100.0^{\mathrm{a}}$ & $100.0^{\mathrm{a}}$ & $100.0^{\mathrm{a}}$ & $100.0^{\mathrm{a}}$ & $100.0^{\mathrm{a}}$ \\
2. KP (g) & $335.7 \pm 10.7^{\mathrm{b}}$ & $366.3 \pm 6.6^{\mathrm{c}}$ & $303.0 \pm 10.5^{\mathrm{a}}$ & $305.4 \pm 9.6^{\mathrm{a}}$ & $289.3 \pm 6.4^{\mathrm{a}}$ \\
3. RP (\%) & $56.7 \pm 2.9^{\mathrm{a}}$ & $65.5 \pm 2.2^{\mathrm{b}}$ & $60.3 \pm 5.1^{\mathrm{a}}$ & $50.0 \pm 2.4^{\mathrm{a}}$ & $53.7 \pm 5.7^{\mathrm{a}}$ \\
4. RL (\%) & $124.1 \pm 7.3^{\mathrm{d}}$ & $92.4 \pm 6.7^{\mathrm{c}}$ & $78.5 \pm 1.9^{\mathrm{b}}$ & $83.9 \pm 9.3^{\mathrm{bc}}$ & $66.4 \pm 1.3^{\mathrm{a}}$ \\
5. PR (\%) & $724.7 \pm 18.6^{\mathrm{b}}$ & $800.0 \pm 28.5^{\mathrm{c}}$ & $653.8 \pm 17.6^{\mathrm{a}}$ & $666.4 \pm 35.4^{\mathrm{a}}$ & $616.2 \pm 31.5^{\mathrm{a}}$ \\
6. EP (\%) & $79.7 \pm 2.9^{\mathrm{a}}$ & $80.4 \pm 2.2^{\mathrm{a}}$ & $80.6 \pm 4.2^{\mathrm{a}}$ & $79.8 \pm 2.0^{\mathrm{a}}$ & $78.4 \pm 2.3^{\mathrm{a}}$ \\
\hline
\end{tabular}

Keterangan (Remarks):

- Huruf di belakang standar deviasi yang berbeda dalam baris yang sama menunjukkan perbedaan yang nyata $(\mathrm{P}<0,05) /$ Different alphabet in back side of standard deviation value in similar row mentions significant different $(\mathrm{P}<0.05)$,

- SR (Tingkat sintasan/Survival rate); KP (Konsumsi pakan/Feed consumption); RP (Retensi protein/Protein retention); RL (Retensi lemak/Fat retention); PR (Pertumbuhan relatif/ Relative growth); EP (Efisiensi pakan/Feed efficiency)

Tabel 4. Rataan komposisi proksimat tubuh dan daging (\% bobot kering) benih ikan patin Table 4. Proximate composition mean of carcass and meat (\% dried weight) for catfish fry

\begin{tabular}{ccccc}
\hline & $\begin{array}{c}\text { Rasio energi-protein } \\
\text { (kkal/g protein) } \\
\text { Energy to protein ratio } \\
\text { (kcal/g protein) }\end{array}$ & \multicolumn{2}{c}{$\begin{array}{c}\text { Komposisi proksimat } \\
\text { Proximate composition }\end{array}$} \\
\cline { 3 - 5 } & & $\begin{array}{c}\text { Air } \\
\text { Water }\end{array}$ & $\begin{array}{c}\text { Protein } \\
\text { Protein }\end{array}$ & $\begin{array}{c}\text { Lemak } \\
\text { Fat }\end{array}$ \\
\hline Tubuh awal & & 79.93 & 16.04 & 3.46 \\
Initial fish carcass & 8.5 & $81.53 \pm 0.61^{\mathrm{c}}$ & $19.16 \pm 0.47^{\mathrm{ab}}$ & $6.42 \pm 0.43^{\mathrm{a}}$ \\
\hline Tubuh akhir & 9.0 & $79.17 \pm 0.20^{\mathrm{b}}$ & $21.37 \pm 1.56^{\mathrm{c}}$ & $7.54 \pm 0.38^{\mathrm{b}}$ \\
Final fish & 9.5 & $81.75 \pm 0.90^{\mathrm{c}}$ & $19.99 \pm 0.86^{\mathrm{bc}}$ & $7.78 \pm 0.21^{\mathrm{b}}$ \\
carcass & 10.0 & $78.09 \pm 0.34^{\mathrm{ab}}$ & $17.20 \pm 0.42^{\mathrm{a}}$ & $10.07 \pm 0.94^{\mathrm{c}}$ \\
& 10.5 & $77.93 \pm 0.73^{\mathrm{a}}$ & $18.50 \pm 1.41^{\mathrm{ab}}$ & $10.99 \pm 0.27^{\mathrm{c}}$ \\
\hline Daging akhir & 8.5 & $81.19 \pm 0.76^{\mathrm{a}}$ & $16.89 \pm 3.05^{\mathrm{a}}$ & $4.99 \pm 0.24^{\mathrm{a}}$ \\
Final meat of & 9.0 & $81.14 \pm 0.48^{\mathrm{a}}$ & $18.68 \pm 4.04^{\mathrm{a}}$ & $7.35 \pm 0.34^{\mathrm{b}}$ \\
fish carcass & 9.5 & $81.11 \pm 0.53^{\mathrm{a}}$ & $16.49 \pm 0.90^{\mathrm{a}}$ & $7.70 \pm 0.28^{\mathrm{b}}$ \\
& 10.0 & $79.05 \pm 3.30^{\mathrm{a}}$ & $16.17 \pm 0.77^{\mathrm{a}}$ & $8.18 \pm 1.35^{\mathrm{b}}$ \\
& 10.5 & $80.48 \pm 0.71^{\mathrm{a}}$ & $14.72 \pm 2.06^{\mathrm{a}}$ & $4.57 \pm 0.09^{\mathrm{a}}$ \\
\hline
\end{tabular}

Keterangan (Remark):

Huruf di belakang standar deviasi yang berbeda dalam baris yang sama menunjukkan perbedaan yang nyata $(\mathrm{P}<0,05)$

Different alphabets in the back side of the standard deviation values in similar row means significant difference $(\mathrm{P}<0.05)$ 
pada rasio energi protein $9,0 \mathrm{kkal} / \mathrm{g}$ protein dan selanjutnya menurun kembali. Kandungan lemak tubuh ikan mengalami peningkatan sejalan dengan naiknya rasio energi protein pada pakan. Kandungan air daging menunjukkan nilai yang hampir sama pada rasio $8,5-9,5 \mathrm{kkal} / \mathrm{g}$ protein namun mengalami penurunan pada rasio 10,0 dan $10,5 \mathrm{kkal} / \mathrm{g}$ protein. Sedangkan kandungan protein daging mengalami peningkatan sampai rasio 9,0 $\mathrm{kkal} / \mathrm{g}$ protein namun selanjutnya menurun kembali. Kandungan lemak daging terjadi peningkatan sampai rasio energi protein 10,0 $\mathrm{kkal} / \mathrm{g}$ protein tetapi pada rasio energi protein $10,5 \mathrm{kkal} / \mathrm{g}$ protein mengalami penurunan kandungan lemak daging.

\section{Pembahasan}

Hasil pemeliharaan benih ikan selama 40 hari menunjukkan bahwa pemberian pakan dengan peningkatan rasio energi protein yang berbeda mempengaruhi jumlah konsumsi pakan benih ikan patin. Pada rasio 8,5 dan 9,0 $\mathrm{kkal} / \mathrm{g}$ protein memiliki energi antara $2.560,5$ $2.691,3 \mathrm{kkal} D E / \mathrm{kg}$ pakan, sedangkan pada rasio $9,5-10,5 \mathrm{kkal} / \mathrm{g}$ protein memiliki energi berkisar 2851,1-3143,7 kkal DE /kg pakan (Tabel 3). Kedua kelompok energi ini bila dibandingkan terlihat bahwa konsumsi pakan rasio 9,5-10,5 $\mathrm{kkal} / \mathrm{g}$ protein lebih rendah dibandingkan dengan rasio 8,5 dan $9,0 \mathrm{kkal} / \mathrm{g}$ protein. Hal ini terjadi karena tingginya kadar lemak di dalam pakan yang mengakibatkan energi tinggi sehingga ikan mengkonsumsi pakan lebih rendah. NRC (1982) menyatakan bahwa pakan yang memiliki kelebihan energi dapat membatasi jumlah pakan yang dikonsumsi termasuk protein dan lemak serta nutrien lainnya yang dibutuhkan oleh ikan. Rendahnya konsumsi pakan menyebabkan rendahnya nutrien-nutrien pakan seperti protein dan lemak yang diserap oleh ikan. Terbukti dengan retensi protein dan lemak pada rasio $9,5-10,5 \mathrm{kkal} / \mathrm{g}$ protein relatif lebih rendah dibandingkan pada rasio 8,5 dan 9,0 $\mathrm{kkal} / \mathrm{g}$ protein.

Keseimbangan energi dan protein dalam pakan sangat berperan dalam menunjang pertumbuhan benih ikan patin. Hasil penelitian menunjukkan bahwa pengaruh energi yang berbeda di dalam pakan mengakibatkan adanya perbedaan retensi protein. Pada rasio $8,5 \mathrm{kkal} / \mathrm{g}$ protein menunjukkan nilai retensi protein yang lebih rendah dibandingkan pada rasio $9,0 \mathrm{kkal} / \mathrm{g}$ protein. Hal ini menunjukkan bahwa kebutuhan energi yang terkandung dalam pakan telah mencukupi kebutuhan energi ikan untuk maintenance tetapi energi untuk pertumbuhan masih lebih rendah dari rasio $9,0 \mathrm{kkal} / \mathrm{g}$ protein. Ini dapat terlihat bahwa kadar protein yang tersimpan dalam daging ikan dimana kadar proteinnya lebih rendah dibandingkan pada kadar protein daging pada rasio $9,0 \mathrm{kkal} / \mathrm{g}$ protein. Tingginya retensi protein pada rasio $9,0 \mathrm{kkal} / \mathrm{g}$ protein diduga akibat benih ikan patin dapat menggunakan energi non protein (lemak dan karbohidrat) lebih banyak untuk memenuhi kebutuhan metabolisme standar sehingga sebagian besar protein yang ada dapat disimpan untuk membangun jaringan tubuh.

Sementara itu pakan dengan rasio 10,0 dan $10,5 \mathrm{kkal} / \mathrm{g}$ protein menunjukkan nilai retensi protein yang lebih rendah dibandingkan dengan rasio energi protein lainnya. Hal ini diduga karena kadar energi yang tinggi di dalam pakan akibat tingginya kadar lemak (1 1,3 dan $15,5 \%$ ) sehingga membatasi konsumsi pakan yang mengakibatkan jumlah protein yang dikonsumsi juga berkurang. Ini dapat dibuktikan dengan kadar protein tubuh pada rasio 10,0 dan $10,5 \mathrm{kkal} / \mathrm{g}$ protein lebih rendah. Akibatnya, retensi protein juga lebih rendah begitu juga dengan kadar protein dalam daging yang menghasilkan pertumbuhan relatif rendah.

Kadar lemak tubuh dan daging ikan patin pada pakan dengan rasio energi protein 8,5 $\mathrm{kkal} / \mathrm{g}$ protein adalah rendah, namun retensi lemaknya tertinggi di atas $100 \%$ (Tabel 4). Hal ini menunjukkan bahwa kandugan lemak pakan pada rasio tersebut belum memenuhi kebutuhan ikan sehingga diduga terjadinya sintesis lemak dari bahan non lemak (karbohidrat dan protein). Pada rasio energi protein $9,0 \mathrm{kkal} / \mathrm{g}$ protein, kadar lemak tubuh dan daging mengalami peningkatan, namun retensi lemak pada rasio tersebut mengalami penurunan dibandingkan dengan pakan dengan rasio energi protein $8,5 \mathrm{kkal} / \mathrm{g}$ protein. Sedangkan untuk rasio energi protein di atas $9,0 \mathrm{kkal} / \mathrm{g}$ protein, kadar lemak tubuh dan daging serta retensi lemak lebih rendah. Keadaan ini menunjukkan bahwa benih ikan patin dapat memanfaatkan energi yang berasal dari lemak daripada karbohidrat.

Adanya kadar protein tubuh dan daging serta retensi protein tertinggi pada rasio energi protein $9,0 \mathrm{kkal} / \mathrm{g}$ protein menyebabkan pertumbuhan relatif yang tinggi, yaitu 
$800 \% \pm 28,5 \%$. Sedangkan pada rasio 9,5-10,5 $\mathrm{kkal} / \mathrm{g}$ protein, walaupun ikan memanfaatkan lemak pakan lebih efisien tetapi karena terbatasnya jumlah pakan yang dikonsumsi maka pada rasio energi protein tersebut menghasilkan kadar protein tubuh dan daging serta retensi protein yang lebih rendah dan sebaliknya kadar lemak tubuh yang lebih tinggi dibandingkan rasio energi protein $9,0 \mathrm{kkal} / \mathrm{g}$ protein. Selanjutnya, rasio energi protein tersebut akan menghasilkan pertumbuhan relatif yang rendah. Dari hasil penelitian Subamia et al. (2003), pakan yang mengandung $35 \%$ protein, $4 \%$ lemak, dan $43,86 \%$ karborhidrat menghasilkan pertumbuhan relatif sebesar $320,4 \%$ pada benih patin berukuran $1,52 \mathrm{~g}$ dengan masa pemeliharaan 6 minggu. Bila dibandingkan dengan pertumbuhan relatif hasil penilitian ini, benih ikan patin berukuran $1,84 \mathrm{~g}$ didapatkan pertumbuhan relatif lebih tinggi $(800,0 \% \pm 28,5 \%)$ dibandingkan penelitian tersebut. Sehingga dapat disimpulkan bahwa kadar protein pakan dapat diturunkan apabila rasio energi protein yang terkandung dalam pakan ditingkatkan.

Konsumsi pakan yang tinggi pada pakan dengan rasio energi protein 9,0 kkal/g protein diimbangi oleh pertumbuhan yang tinggi pula. Pada rasio energi protein yang lain, konsumsi pakan yang lebih rendah dan diimbangi dengan pertumbuhan yang rendah pula. Dengan demikian menyebabkan efisiensi pakan yang relatif hampir sama antar rasio energi protein (Tabel 4).

\section{KESIMPULAN}

Berdasarkan hasil penelitian ini dapat disimpulkan bahwa pada kadar protein pakan $30 \%$ dengan rasio energi protein 9,0 kkal DE/g protein menghasilkan pertumbuhan maksimum bagi benih ikan patin.

\section{DAFTAR ACUAN}

Brett, J.R. \& Grovers, D.D. 1979. Physiological energetic. In W.S. Hoar. D.J. Randall and J.R. Breet (Eds.). Fish Physiology Vol. VIII. Acad. Press. New York, p. 279-351.
Furuichi, M. 1988. Dietary requirement, In Watanabe. T. (Ed.). Fish Nutrition and Mariculture. Department of Aquatic Bioscience. University of Fisheries. JICA. Tokyo, p. 878.

Kurnia, A. 2002. Pengaruh pakan dengan kandungan protein dan rasio energi protein yang berbeda terhadap efisiensi pakan dan pertumbuhan benih ikan Baung (Mystus nemurus CV.). Tesis. Program Pascasarjana. Institut Pertanian Bogor. Bogor. Bogor, $54 \mathrm{hlm}$.

Lovell, R.T. 1989. Nutrition and Feeding of Fish. New York Van Nostrand Reinhold, 217 pp.

NRC. 1982. Nutrient Requirement of Warmwater Fishes and Shellfishes (Rev. Ed). Acad. Press. Washington D.C., 86 pp.

Rabegnatar, I N.S. \& Hidayat, W. 1992. Estimasi perbandingan optimal energi dan protein dalam pakan buatan untuk pembesaran benih ikan lele (Clarias bratachus) dalam keramba jaring apung, Prosiding Seminar Hasil Penelitian Perikanan Air Tawar. Balai Penelitian Perikanan Air Tawar. Bogor, p.1928.

Subamia, I W., Suhenda, N., \& Tahapari, E. 2003. Pengaruh pemberian pakan buatan dengan kadar lemak yang berbeda terhadap pertumbuhan dan sintasan benih ikan jambal Siam (Pangasius hypophthalmus). J. Pen. Perik. Indonesia, 9(1): 37-42.

Suhenda, N., Setijaningsih, L., \& Suryanti, Y. 2003. Penentuan rasio antara kandungan karbohidrat dan lemak pada pakan benih ikan patin jambal (Pangasius sutchi). J. Pen. Perik. Indonesia, 9(1): 21-29.

Suryanti, Y., Priyadi, A., \& Mundriyanto, H. 2003. Pengaruh rasio energi dan protein yang berbeda terhadap efisiensi pemanfaatan protein pada benih baung (Mystus nemurus C.V.). J. Pen. Perik. Indonesia, 9(1): 31-36.

Takeuchi, T. 1988. Laboratory work chemical evaluation of dietary nutrition. In Watanabe T. Fish Nutrition and Mariculture. JICA Textbook the General Aquaculture Course. Tokyo: Kanagawa International Fisheries Training Center, p. 179-229. 